\title{
Customer Satisfaction and Quality of Service at KFC Kupang
}

\author{
Aryanto Mengi Dju Bire ${ }^{1, *}$ Ronald P. C. Fanggidae ${ }^{1}$ Antonio E. L. Nyoko ${ }^{1}$ \\ ${ }^{1}$ Department of Management, Nusa Cendana University, Kupang, Indonesia \\ *Corresponding author. Email: adjubire@gmail.com
}

\begin{abstract}
Because it's cheap, quick, and convenient, fast food has become a way of life for many people. Kentucky fried chicken is one of the many fast-food establishments in Kupang City (KFC). KFC, which has three locations in Kupang City, is the subject of this investigation. Customer satisfaction at KFC Kupang City was examined as a result of this research. This study employs quantitative methodologies in its investigation. All KFC consumers in Kupang City were included in this study, conducted in three different parts of the city. A total of 100 persons participated in this research. The classical assumption test, multiple regression test, t-test, f-test, and coefficient of determination test were utilized in the data analysis. - In Kupang City KFC, Physical Evidence, Concern, and Responsiveness have no significant effect on Consumer Satisfaction, whereas Reliability and Assurance have a substantial effect on Consumer Satisfaction. This indicates that service quality elements such as Physical Evidence, Concern, and Reliability substantially impact customer satisfaction in Indonesia based on the simultaneous test findings. KFC in the city of Kupang.
\end{abstract}

Keywords: Customer satisfaction, Kupang city, Service quality.

\section{INTRODUCTION}

Customer satisfaction will be achieved when the company can provide quality services. Once the customer is satisfied, he will compare the services from one company with other companies. Satisfaction at a high level will lead customers to return to make purchases and even recommend them to others.

Superior and consistent service quality can foster customer satisfaction and provide various benefits [1] such as: (1) The relationship between the company and its customers becomes humorous; (2) Provide a good basis for repeat purchases; (3) Can encourage the creation of consumer loyalty; (4) Providing word-ofmouth recommendations that are profitable for the company; (5) The company's reputation is good in the eyes of consumers; (6) Earned profit can be increased.

Kentucky Fried Chicken (KFC) is one of the oldest fast food restaurants in Indonesia and even in the world. KFC restaurants are very developed and have many outlets in several areas in Indonesia. Several other fast food restaurant companies that has also existed in Indonesia to date are $\mathrm{McD}, \mathrm{CFC}, \mathrm{A} \& \mathrm{~W}$, and fast food restaurants other local. KFC is a fast-food restaurant that serves chicken products and other products related to chicken meat. KFC is also located in Kupang City which is spread over 3 strategic locations, at Flobamora Mall (Jl. WJ Lalamentik Oebufu), J1 Frans Seda (Oesapa Barat Kelapa Lima), and KFC Kampung Solor. The number of fast food restaurants in Kupang City that are not far behind KFC, will lead to competition in serving quality products that are liked by the public, so KFC must be very aware of this competition, KFC must provide good quality products and services if they do not want customers move to other restaurants. In the service sector, service is the main thing, if the service is good it will give a good picture of the company. The services provided by KFC must be good to give a good picture of KFC.

There are five main dimensions of service quality according to Parasuraman, in Tjiptono [1], namely physical evidence (tangible), responsiveness, reliability, assurance, and empathy. Quality strategy The service used certainly has an impact on the level of customer visits at KFC.

There is a close relationship between service quality and customer satisfaction. By obtaining good service quality, customers will be motivated to establish a strong relationship with the company. Therefore, 
companies must understand and carefully consider the expectations and customer needs

\section{LITERATURE REVIEW \& HYPOTHESIS DEVELOPMENT}

\subsection{Quality of Service}

Quality is the main or complementary activity that is not directly involved in the product manufacturing process, but places more emphasis on service transactions between buyers and sellers [2].

There are two main factors that affect Service Quality according to Parasuraman in [1], the expected service and the perceived service. The dimensions and attributes of the SERVQUAL model consist of:

1) Tangible; In terms of the company's physical buildings, the equipment and materials it uses, and the appearance of its people.

2) Empathy; It signifies that the company cares about its consumers, operates in their best interest, and provides personalized service and convenient operating hours.

3) Responsiveness; When it comes to the capacity of staff to assist customers and reply to their demands, as well as to inform customers when services will be given and then deliver them quickly, responsiveness is a crucial factor.

4) Reliability; A firm needs to be reliable because it can provide accurate services the first time without any errors and provide its services on schedule.

5) Assurance; Customer trust in the company can be fostered by the behaviour of staff, which in turn creates a sense of security for customers.

\subsection{Customer/Consumer}

Satisfaction is a state of mind that is influenced by one's experiences. An evaluation of a product or service's features and characteristics that provide a level of consumer pleasure associated with consumer consumption is called satisfaction. [3]. The magnitude or dimensions of customer satisfaction might reveal factors that influence it [4] as follows:

1) Stay Loyal Satisfied; First and foremost, keep your loyalty to your employer. Satisfied customers are more likely to become repeat or long-term customers. Products that customers are satisfied with potential to be purchased again and again by those customers.

2) Buying the offered; The impulse to buy another product or meal because of the desire to recreate a positive experience and prevent a negative one.
3) Recommending Products; Satisfaction generates positive word-of-mouth communication. For example, customers can make recommendations to other potential customers and speak well of their company's products and services

4) Willing to Pay More; Customers are willing to pay more for a product or service they are satisfied with. As a result of the increased price, people assume that the product's quality is also better.

5) Giving Feedback; Although the customer is satisfied, they constantly want more. Customers will then provide comments or suggestions so that their desires can be met.

\subsection{The Effect of Service Quality on Consumer Satisfaction Service}

Providing clients with an incentive to build a longterm relationship with a firm is a critical component of quality. Customers' expectations and demands might be better met if a company has a long-term relationship with them. Because of this, organizations can boost consumer happiness, which in turn increases client loyalty, which in turn creates customer loyalty or loyalty to companies that give excellent quality [5]. To improve and sustain quality in the company's products and services, service quality is a continual improvement work process, according to Kotler [6]. Customer satisfaction and service excellence are closely linked. It is excellent and satisfactory if the service is received following customer expectations, and it is perfect and quality if the service exceeds customer expectations. When a company's consumers are happy and confident in the quality of its services, this can lead to increased sales and a positive brand image.

The thinking framework in this study is as shown in figure 1 .

$\mathrm{H}_{1}$ : Tangible $\left(\mathrm{X}_{1}\right)$ has an effect on Kupang City KFC Consumer Satisfaction (Y).

$\mathrm{H}_{2}$ : Concern $\left(\mathrm{X}_{2}\right)$ has an effect on Consumer Satisfaction of KFC Kupang City (Y).

$\mathrm{H}_{3}$ : Reliability $\left(\mathrm{X}_{3}\right)$ has an effect on Consumer Satisfaction of KFC Kupang City (Y).

$\mathrm{H}_{4}$ : Responsiveness $\left(\mathrm{X}_{4}\right)$ has an effect on Consumer Satisfaction of KFC Kupang City (Y).

$\mathrm{H}_{5}$ : Guarantee $\left(\mathrm{X}_{5}\right)$ has an effect on KFC Kupang City Consumer Satisfaction (Y).

$\mathrm{H}_{6}$ : Quality of Service which consists of Physical Evidence $\left(\mathrm{X}_{1}\right)$, Empathy $\left(\mathrm{X}_{2}\right)$, Reliability $\left(\mathrm{X}_{3}\right)$, Responsiveness $\left(\mathrm{X}_{4}\right)$, Assurance $\left(\mathrm{X}_{5}\right)$ influence together on Consumer Satisfaction (Y). 


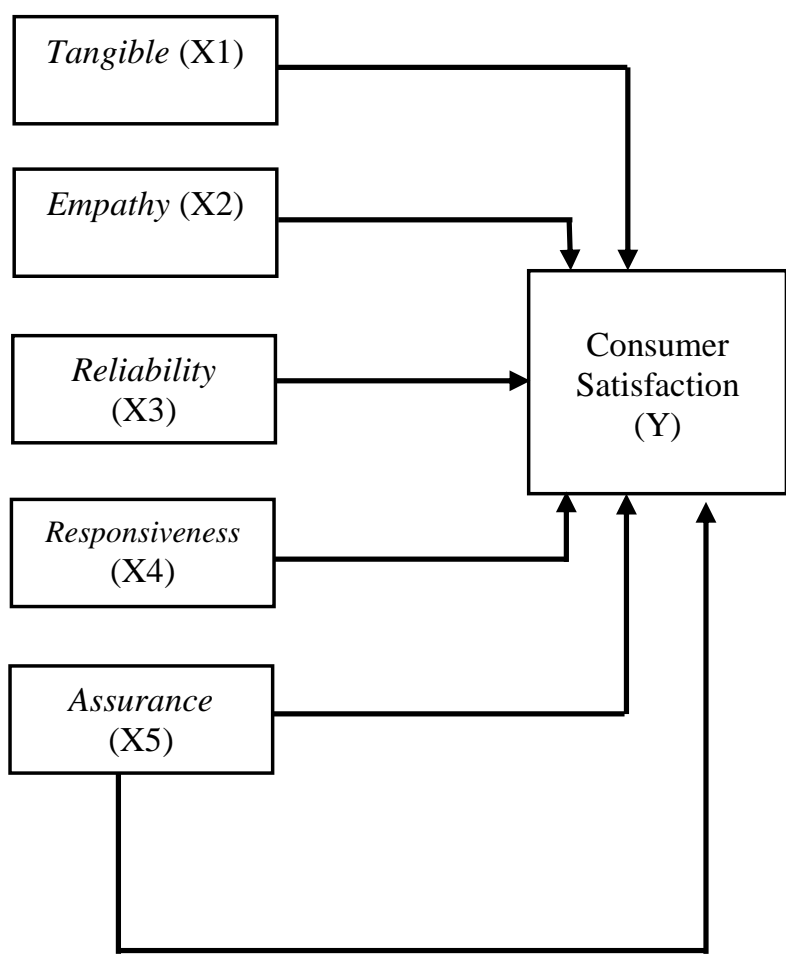

Figure 1 Thinking Framework

\section{METHOD}

This research uses quantitative research. The population in this study were all customers at KFC fast-food restaurants spread across three areas in Kupang City. The sample of this study amounted to 100 people. Data processing and analysis were carried out using the SPSS program.

\section{RESULTS AND DISCUSSION}

\subsection{The Effect of Physical Evidence on Consumer Satisfaction}

Based on the results of the t-test (partial) it shows that the Dimension of Physical Evidence partially does not significantly affect Consumer Satisfaction at KFC, which is indicated by the value of count $(1.650)<\mathrm{t}-$ table (1.985) and significance (0.102) > alpha (0.05) then $\mathrm{HO}$ is accepted. This can be interpreted that the consumer's assessment of the Quality of Physical Evidence Services at KFC varies, depending on the perception of the consumer concerned, according to conditions.

Based on the indicator scores in the Physical Evidence Dimension which consists of three (3) indicators, namely satisfaction with the facilities provided by KFC (Wifi), satisfaction with the comfort of the dining area, and satisfaction with the cleanliness of the work equipment used by employees, which of the three indicators shows that The highest score is an indicator of satisfaction with the comfort of a place to eat and satisfaction with the cleanliness of work equipment used by employees with a score of both indicators both 425 .

According to the first hypothesis, consumer Satisfaction with Physical Evidence has no substantial impact because other dimensions take precedence. According to Tjiptono [1] client happiness is closely linked to the quality of the service provided. Service that exceeds customers' expectations is seen as excellent in quality and satisfaction if the service is received or believed to be appropriate and expected. We may conclude from this study that tangible goods can have an impact on customer satisfaction. There is no evidence that physical evidence has an impact on customer satisfaction at KFC in this study.

\subsection{Effect of Concern for Customer Satisfaction}

Based on t-test (partial) showed that the dimension of Concern partially not significantly affect customer satisfaction at KFC, which is indicated by the value of $t$ the $(0.927)<t$-table $(1.985)$ and significant (0.375)> alpha (0.05) then $\mathrm{H} 0$ is accepted.

Based on the indicator score in the Dimension of Concern which consists of three (3) indicators, namely satisfaction of attention to customers, satisfaction to always give greetings when providing service, and satisfaction in terms of prioritizing the interests of customers, which of the three indicators shows that the highest score is an indicator of satisfaction. In terms of prioritizing the interests of customers with a score of 407 . This indicates that consumers are satisfied when employees prioritize the interests of consumers rather than the interests of their own employees so that consumers feel neglected by employees but feel fully cared for.

This is in line with the opinion of Tjiptono [1] who said that service quality has a close relationship with customer service Customer satisfaction. If the perceived service is appropriate, expected, then the quality of service is perceived as good and satisfactory, and if the service received exceeds customer expectations, then the quality of service is perceived as very good and quality. With this, it is clear that Concern effect Consumer Satisfaction. However, in this study, Care does not significantly affect Consumer Satisfaction at KFC because there are other dimensions of Service Quality that are more dominantly influential. 


\subsection{Effect of reliability against Customer Satisfaction}

Based on $t$ test (partial) showed that the dimension of reliability partial significantly influence consumer satisfaction at KFC, which indicated valuet (3.169)> t-table (1.985) and significant (0.002) <alpha $(0,05)$ then $\mathrm{H}_{0}$ is rejected. The Reliability dimension has a significant effect because consumers prefer the elements that exist in this dimension which are employees who always greet before serving consumers, employees who are honest in providing services and also employees who serve carefully and try to avoid mistakes.

Based on the indicator scores in the Reliability dimension which consists of three (3) indicators, namely satisfaction with employees who always give greetings before serving customers, satisfaction with employees who are honest in providing services, and satisfaction with employees who serve carefully and try to avoid mistakes, which of the three indicators shows that the highest score is an indicator of satisfaction with honest employees in providing services with a score of 423. This implies that consumers will feel very satisfied when employees in serving employees behave and behave honestly with consumers.

Based on the third hypothesis, it can be seen that consumer satisfaction, one of which is influenced by satisfaction with employees who always give greetings before serving customers, satisfaction with employees who are honest in providing services, and satisfaction with employees who serve carefully and try to avoid mistakes. Tjiptono [7] suggests that Service Quality has a close relationship with Consumer Satisfaction. If the service meets or exceeds expectations, the perceived service quality is excellent. With this, it is clear that the dimension of reliability has an effect on customer satisfaction. This is in line with research conducted by [8]-[10] which shows that partially the reliability variable has a significant effect on consumer satisfaction.

\subsection{Influence Response to Customer Satisfaction}

Based on $t$ test (partial) indicates that Dimensional Response partially not significantly affect customer satisfaction at KFC, which is indicated by the value of the $(1.018)<$ ttable $(1.985)$ and significant $(0.312)>$ alpha $(0.05)$ then $\mathrm{HO}$ is accepted.

Based on the indicator score in the Reliability Dimension which consists of three (3) indicators, namely satisfaction ready to help customers, satisfaction with the speed in service, and satisfaction with smooth communication, which of the three indicators shows that the highest score is an indicator of satisfaction with smooth communication with a score of 417. This indicates that smooth communication allows consumers to get clear information so that they do not confuse consumers/customers when they are going to order food or other things or when they want to need information about something.

Tjiptono [7] suggests that Service Quality has a close relationship with Consumer Satisfaction. If the perceived service meets customer expectations, the perceived service quality is acceptable; if the perceived service meets or exceeds customer expectations, the perceived service quality is exceptional. With this, it is clear that the dimension of Responsiveness has an effect on Consumer Satisfaction. However, in this study, responsiveness did not significantly affect consumer satisfaction at KFC KFC because there were other dimensions of service quality that had a more dominant effect.

\subsection{Influence Assurance of Customer Satisfaction}

Based on $t$ test (partial) indicates that Dimensional Security partial significantly influence consumer satisfaction at KFC, which is indicated by the value oftthe (2.703)> ttable (1.985) and significant (0.008) <alpha ( 0.05$)$ then $\mathrm{H} 0$ is rejected. Thus it can be interpreted that the higher the level of the Assurance Dimension will have an impact on Consumer Satisfaction at KFC.

Based on the indicator scores in the Assurance Dimension which consists of three (3) indicators, namely satisfaction with the services provided are very good, satisfaction with employees who really understand what the customer wants, and satisfaction with employees who have good knowledge about the products contained in KFC, which of the three indicators shows that the highest score is an indicator of satisfaction with employees who have good knowledge of the products available at KFC with a score of 421. This indicates that good knowledge of products really helps consumers in determining what products they want and also when consumers want to order food, employees are not confused by what consumers order because employees have mastered the existing products well.

The Guarantee dimension emphasizes the wisdom of KFC in providing a sense of security, free from risk or doubt to consumers. So with the guarantee provided by the KFC, the consumers who come to the KFC feel satisfied. This is due to the bonus facility, namely by providing a sense of comfort and security at the time of work and in performing services. This 
is in accordance with the opinion of Yazid (2008) which explains that assurance includes reliability or guarantee of competence, trustworthiness, honesty of service providers, possession of skills and knowledge needed to perform services, and credibility.

This research is in line with that conducted by [8], which shows that partially the guarantee variable has a significant effect on consumer satisfaction.

\subsection{The Effect of Service Quality which consists of Physical Evidence, Concern, Reliability, Responsiveness, Guarantee of Consumer Satisfaction}

Customers can be persuaded to stick with a company's products and services if the service quality is excellent. When it comes to maintaining consumers, customer satisfaction is a major aspect.

Based on the results of the F test, it shows that theF valuecalculated (66.929) > Ftable (2.47) then $\mathrm{H} 0$ is rejected so it can be concluded that the Service Quality variable consisting of Physical Evidence, Concern, Reliability, Responsiveness, Guarantee simultaneously has a significant effect on Consumer Satisfaction at KFC, because in order to maintain Customer Satisfaction, the Quality of Service in the form of Physical Evidence, Care, Reliability, Responsiveness, Guarantee are important factors. When a corporation is able to consistently improve and maintain the quality of its products and services, this is referred to as "service quality" by Kolter [6]. Customers can be persuaded to stick with a company's products and services if the service quality is excellent. In order to keep clients happy and loyal, it is critical to provide high-quality service in line with the market's demands. In addition, Chandra [11] states that High service quality in a business creates customer satisfaction. After receiving a satisfactory product or service, the consumer will compare the services received. If consumers feel really satisfied, they will repurchase and recommend to others to buy in the same place.

The dimensions of Physical Evidence, Concern, and Responsiveness partially have no significant effect on Consumer Satisfaction, but in the simultaneous test, the Dimensions of Physical Evidence, Concern, Reliability, Responsiveness, Assurance have a significant simultaneous effect this is due to two (2) other dimensions namely Reliability and Assurance Dimensions This dominant influence is seen from the regression coefficient of the Dimension of Reliability and Assurance which is the largest compared to the others.

Based on the results of the analysis of determination which shows that the percentage of independent influence, namely Service Quality (Physical Evidence, Concern, Reliability, Responsiveness, Assurance) on the dependent variable of Consumer Satisfaction is $78.10 \%$ while the remaining $21.90 \%$ is influenced by other variables not included in this research.

This research is in line with that conducted by [8], which shows that the Service Quality variable simultaneously has a significant effect on consumer satisfaction.

\section{CONCLUSION}

It can be concluded that, based on partial test results, Physical Evidence, Concern, and Responsiveness have no significant effect on Consumer Satisfaction in Kupang City KFC whereas Reliability and Assurance have a significant effect on Consumer Satisfaction in Kupang City. This indicates that service quality elements such as Physical Evidence, Concern and Reliability have a substantial impact on customer satisfaction in Indonesia based on the simultaneous test findings. $\mathrm{KFC}$ in the city of Kupang.

The study has several recommendations, that is KFC Kupang City is expected to maintain and continue to improve the quality of service in the form of Reliability Dimensions where employees must remain honest in providing services to consumers, and employees continue to serve carefully and always try to avoid mistakes, so that consumers remain satisfied with the attitudes and responses of employees to consumers. In addition, KFC Kupang City is expected to continue to maintain and improve the quality of service in the form of Dimensions of Guarantee to consumers by continuing to provide good service to consumers, being able to understand what needs consumers want and good knowledge about the products contained in KFC so that consumers remain satisfied with the quality. services provided by the KFC.

\section{REFERENCES}

[1] F. Tjiptono, Pemasaran Jasa (Prinsip, Penerapan, dan Penelitian). Yogyakarta: Andi Offset, 2016.

[2] Z. Yamit, Manajemen Kualitas Produk dan Jasa. Yogyakarta: Ekonesia, 2010.

[3] C. Lovelock, J. Wirtz, and J. Mussry, Pemasaran Jasa, 7th ed. Jakarta: Erlangga, 2011.

[4] P. Kotler and K. L. Keller, Marketing management, 15th ed. Jakarta: Erlangga, 2016.

[5] N. N. Yuliarmi and P. Riyasa, "Analisis faktorfaktor yang mempengaruhi kepuasan pelanggan 
terhadap pelayanan PDAM kota denpasar," Bul. Stud. Ekon., vol. 12, no. 1, pp. 9-28, 2007, [Online]. Available: https://www.researchgate.net/publication/265262 053\%0AANALISIS.

[6] J. E. Panjaitan and A. L. Yuliati, "Pengaruh kualitas pelayanan terhadap kepuasan pelanggan pada JNE cabang Bandung," DeReMa J. Manaj., vol. 11, no. 2, pp. 265-289, 2016, doi: 10.24929/feb.v6i2.268.

[7] F. Tjiptono, Strategi Pemasaran, Edisi III. Yogyakarta: Andi Offset, 2008.

[8] N. Afifah and N. Q. Wijaya, "Pengaruh kualitas pelayanan, harga, dan citra merk terhadap kepuasan pelanggan pada butik Syafa Sumenep," Universitas Wiraraja, 2019.

[9] Y. Ningsih and Suryalena, "Pengaruh kualitas pelayanan terhadap kepuasan konsumen pada PT Kereta Api Indonesia (persero) divisi regional ii Sumatra Barat Padang Pariaman," JOM FISIP, vol. 5, pp. 1-5, 1997.

[10] Y. Dedhi, "Pengaruh kualitas pelayanan terhadap kepuasan (Studi pada wisatawan pada hotel kelimutu ecolodge)," Universitas Nusa Cendana, 2017.

[11] G. Chandra, Strategi dan program pemasaran. Yogyakarta: Andi Offset, 2005. 